\title{
Active Teaching Methodology Applied in the Training of Undergraduate Dental Students: Use of Video-Lesson
}

\author{
Metodologia Ativa de Ensino Aplicada na Formação de Graduandos de Odontologia: \\ Utilização de Vídeo-Aula
}

\author{
Sablina Muniz Santos*a; Lívia Duarte Santos Lopes ${ }^{\text {ab }}$; Mila Oliveira Santos Viana ${ }^{\text {ab }}$; Vithor Hugo Rodrigues Costa \\ Nascimento $^{\text {a }}$ Regina Moraes de Oliveira ${ }^{a}$; Sirleide Souza Coêlho ${ }^{a}$
}

\author{
${ }^{a}$ Differential Integral College, Dentistry Course. PI, Brazil. \\ ${ }^{b}$ Dental Research Center São Leopoldo Mandic, Stricto Sensu Graduate Program in Dental Clinics. SP, Brazil; \\ *E-mail: smubiz815@gmail.com \\ Recebido em: 23/01/19 \\ Aprovado em: 18/06/19
}

\begin{abstract}
The goal of the present study was to evaluate the effectiveness of the active video-class methodology in the teaching-learning process, ascertaining the understanding, clarity and absorption through a pre-structured questionnaire. The sample consisted of 35 students, who were enrolled in the fixed prosthesis discipline, between the age of 19 and 31 years old. A videotape with provisional crown content was applied to the sample and, after a pre-structured questionnaire with 5 questions with objective and subjective questions related to the class. In the results obtained two people did not miss any of the questions, corresponding to $5.7 \%$ of the total number of students. Meanwhile, $57.1 \%$ of the students erred only one question in that they are equivalent to 20 students of the sample, $34.3 \%$ did not answer right two questions of the questionnaire, in the total of twelve people and finally $2,9 \%$ missed 3 questions, represented by only 1 person. It was evidenced that most of the questions students achieved success above $80 \%$. The use of videoconference as an active teaching methodology in the academic environment has shown satisfactory results when applied in the classroom as an aid material, since most of the students have had success in most of the questions with the use this tool. The active methodologies can be a satisfactory alternative in the teaching-learning process to assist the teacher in the classroom, and its use can yield good results in the training of health professionals.
\end{abstract}

Keywords: Audiovisual Aids. Educational Technology. Learning.

\section{Resumo}

O objetivo do presente trabalho foi avaliar a eficácia da metodologia ativa vídeo-aula aplicada aos alunos de odontologia de uma instituição de ensino superior no processo de ensino aprendizagem, averiguando o entendimento, clareza e absorção, através de um questionário préestruturado. A amostra constou de 35 alunos devidamente matriculados na disciplina de prótese fixa, com idades que variavam entre 19 a 31 anos. Foi administrado uma vídeo-aula com conteúdo de coroas provisória e logo após responderam um questionário pré-estruturado com 5 perguntas com questões objetivas e subjetivas relacionadas a aula. Nos resultados obtidos duas pessoas não erraram nenhuma das questões, correspondendo 5,7\% do total de alunos. Já 57,1\% dos alunos erraram apenas uma questão no que equivalem 20 alunos da amostra, 34,3\% não acertaram duas questões do questionário, no total de 12 pessoas e por fim 2,9\% erraram 3 questões, representado por apenas 1 pessoa. Ficou evidenciado que a maioria das questões os alunos obtiveram êxitos acima de 80\%. O emprego da vídeo-aula como uma metodologia ativa de ensino, no ambiente acadêmico, mostrou resultados satisfatórios ao ser aplicada em sala de aula como material de auxilio, visto que a maioria dos alunos tiveram êxitos na maior parte das questões com a utilização desta ferramenta. As metodologias ativas podem ser uma alternativa satisfatória no processo de ensino- aprendizagem para auxiliar o professor em sala de aula, e sua utilização pode render bons resultados na formação de profissionais da saúde.

Palavras-chave: Recursos Audiovisuais. Tecnologia Educacional. Aprendizagem.

\section{Introduction}

Pedagogical approaches grounded in the practice of teaching active methodology have been formed and consolidated in the academic environment, with the aim of forming skilled professionals, with technical, ethical, political and scientific competence, and empowered to intervene in the context of health ${ }^{1}$.

The education process, when it involves the courses in the area of health, is of great complexity, by tackling the commitment to train professionals prepared to address the needs of the population. The traditional education model, directed at the figure of the professor, has been questioned and criticized by the fact that the student is an inactive subject in the obtaining of knowledge. On the occasion of conflict between the traditional methodology and active, identifying the academic point of view it is essential to improve the teaching-learning process in higher education institutions ${ }^{1}$.

The application of active methodologies became inherent in the use of educational methods in the education of undergraduate courses directed to health. Overcoming the banking model of education, with the aim of going beyond the limits of professionals that only reproduced the knowledge, promoting the formation of thoughtful and critic professionals, overthrowing the mechanicity and renewing knowledge ${ }^{2}$. 
The use of active learning methodologies, among them the reversed classroom, implies a change of the student's attitude, who should be the protagonist of his or her own learning. Among the difficulties that the student faces to carry out preparatory tasks, is the lack of time, the strong culture that the only way of learning are the theoretical lessons taught in person by the teacher and the need of the student to leave his or her comfort zone ${ }^{3}$.

Although the scholars may choose to live simulations, the video when prepared with precaution can be a useful option for help in teaching difficult techniques. The favorable conducts and resulted from learning, obtained from media resources, as part of the pre-clinical exercises, suggest that they are suited and can provide a positive student learning in an individual way ${ }^{4}$.

It is assumed that the employment of audiovisual feature can be beneficial for the understanding of the surgical technique, since it incorporates the image of the professor to practical demonstration of the procedure, with a richness of details, exemplifying and providing technical and scientific support. It is understood as all and any appeal, those who actually "contribute to learning" and "represent added value to the work of the professor", qualifying even more the activity of the professors 5 .

The production of video lessons has been the strategy most commonly advocated in the literature regarding the preclass moment. Bishop Verlenger demonstrates that the use of video lessons is superior to the reading of the text books in the reversed classroom ${ }^{6.7}$

Thus, the objective of this work was to evaluate the effectiveness of the active methodology video-lesson in the teaching-learning process, ascertaining the understanding, clarity and absorption, through a pre-structured questionnaire applied to students of Dentistry of an institution of Higher Education.

\section{Material and Methods}

It is a descriptive study of nature applied, with a quantitative approach per survey. This research was conducted in a classroom of a Private Higher Education Institution, in the city of Teresina-PI. The research participants were all students in the Dentistry Course duly enrolled in the discipline of fixed prosthesis. The research took place in February 2017, and consisted of a sample corresponding to 35 students, with ages ranging from 19 to 31 years.

The data collection happened even before this subject to be applied in the classroom. Upon being explained the objectives of the survey, there was a presentation of the video-lesson with the described programmatic content, and the signature of the TCLE (Free and Informed Consent Term). It was performed through a pre-structured questionnaire with closed and open questions about the theme, formulated on the basis of studies in the literature, primarily in the questionnaire containing questions about identification (name) of the student.

The questions in the questionnaire sought to analyze the teaching active methodology applied to dentistry students in the learning process for the odontological practice, verifying the understanding of clarity and absorption.

Presentation of video-lesson to students by the researcher was initially done, soon after explanation of what it was composed, approaching the time and the content of the same. Then the purpose of the research was explained and clarified to the students that the video-lesson would be made available to students as supportive material.

To the students of the fixed prosthesis discipline a videolesson was presented for 25 minutes, which was drawn up by the researcher with the programmatic content of the discipline (provisional crowns). The video-lesson was composed of a previous explanation, which presents slides on the subject with audio explaining each item. After the explanation, to the classroom three videos were attached illustrating the confection of provisional prosthesis using direct techniques, showing first the technique of ball (Figure 1), soon after the technique of silicone matrix (Figure 2) and finally, the technique of the facet (Figure 3 ).

Figure 1 - Video-lesson (technique of ball)

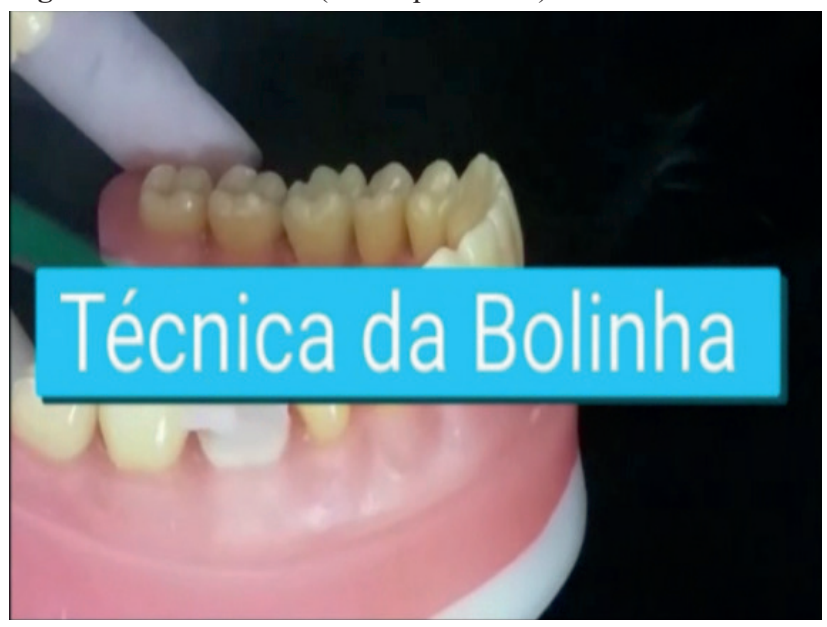

Source: The authors.

Figure 2 - Video-lesson (technique of matrix)

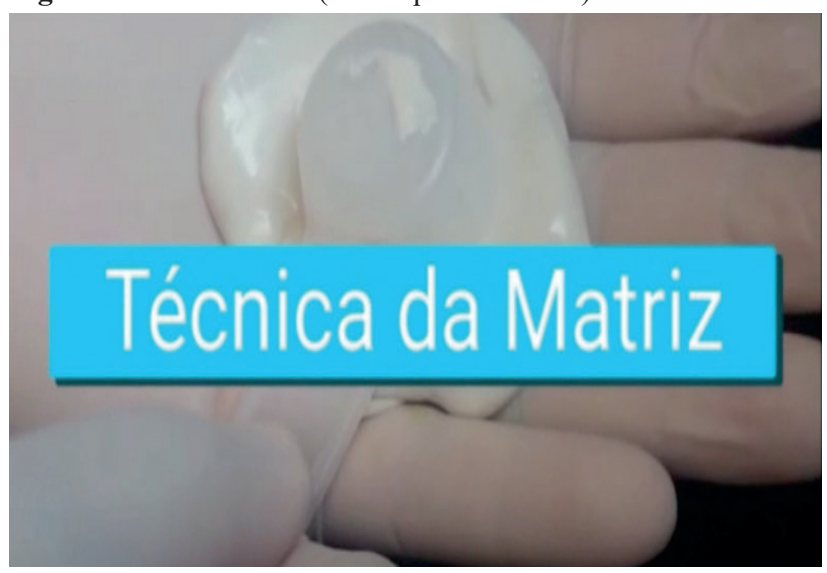

Source: The authors. 
Figure 3 - Video-lesson (technique of matrix)

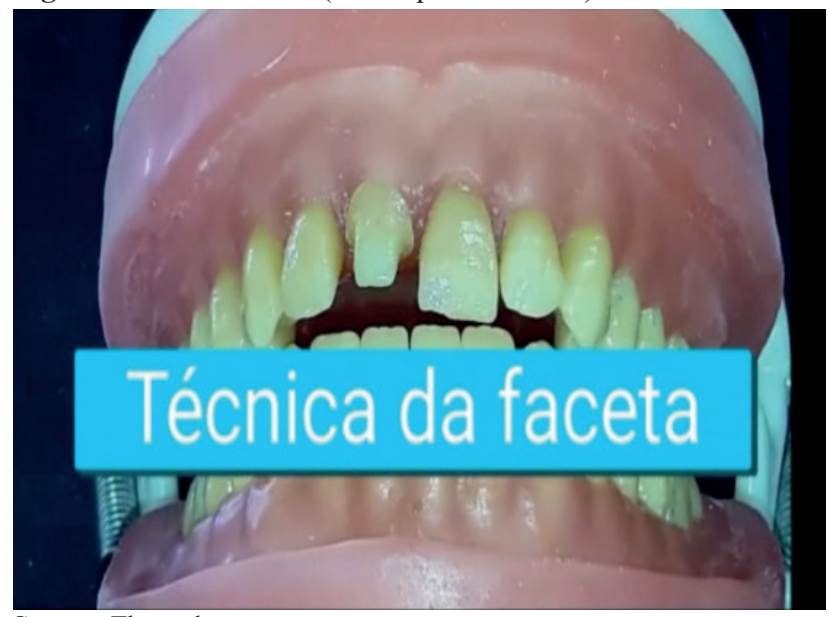

Source: The authors.

Then a pre-structured questionnaire composed by five questions was applied, four objective questions with alternatives from $\mathrm{A}$ to $\mathrm{E}$ and subjective, of summation. The questions were formulated on the basis of the issues dealt with in the video-lesson. The questionnaire duly answered was collected by the researcher.

The data obtained from the questionnaires were organized in the form of tables and graphs, with the successes and errors of each student, using the statistical spreadsheets Microsoft Excel 2007 for Windows 7 for the generation of results. The test used was the Mann-Whitney test and a descriptive analysis was performed with values of frequency and percentage.

This study was submitted to the Ethics and Research Committee - CEP of FACID, through the Platform Brazil having its approval under the protocol number 57345216.9.0000.5211.

\section{Results and Discussion}

After the application of the video-lesson, the individual performance of each student was evaluated through a questionnaire, by means of percentages in order to assess the amount of hits and errors in the questionnaire (Figure 4). The average amount of questions with correct answers was 3.65 $( \pm 0.64)$ and errors $1.34( \pm 0.64)$. First the number of mistakes was observed, taking into consideration how many people erred one, two, three, four or five questions. Of the sample interviewed it was demonstrated that none of the people erred 4 or 5 questions.

Figure 4 - Quantity wrong questions by the students.

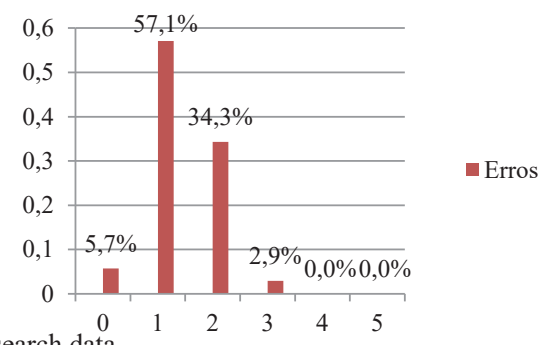

Source: Research data.
Upon assessing the issues of the questionnaire separately for the amount of hits and errors of undergraduates for questions, it became clear that the majority of the questions the students scored successes above $80 \%$, in which the fifth question stands by presenting $100 \%$ of correct answers. However, the question four draws attention, because they showed a high rate of errors, representing $94.3 \%$ of the students statistically (Figure 5), this being the only subjective question of the questionnaire.

Figure 5 - Number of hits and errors per question

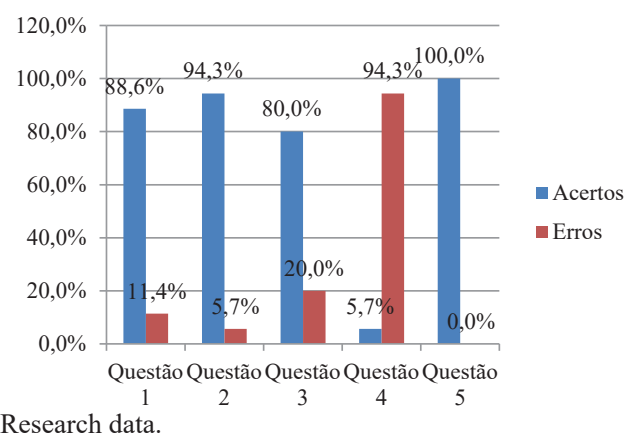

Int the present study there were no significant difference in scores between genders, both male and female had the same results (Table 1).

Table 1- Difference in scores between genders.

\begin{tabular}{|c|c|c|c|}
\hline Gender & Hits & Errors & Value of p \\
\cline { 1 - 3 } Male & $3.72( \pm 0.90)$ & $1.27( \pm 0.90)$ & \multirow{2}{*}{0.628} \\
\cline { 1 - 3 } Female & $3.62( \pm 0.49)$ & $1.37( \pm 0.49)$ & \\
\cline { 1 - 3 } Total & $\mathbf{3 . 6 5 ( \pm \mathbf { 0 . 6 4 } )}$ & $\mathbf{1 . 3 4 ( \pm \mathbf { 0 . 6 4 } )}$ & \\
\cline { 1 - 3 } & & \multicolumn{2}{|c}{} \\
\end{tabular}

Source: Research data.

Thus, it was noticed that the students showed no major difficulties in the resolution of questions after the implementation of video-lesson, since according to the statistical data over half of the students errored just a question. In a similar study conducted by Nikzad et al. ${ }^{4}$ in which the comparison of two groups was done in the discipline of fixed prosthesis, where two groups were instructed by the method of live presentation before participation in the research however the group B received a copy of an instructional video on the subject, results indicated that students exposed to extra resources with new technologies had a superior performance in some practical steps, for example, laboratory procedures. Therefore, the use of technological resources through demonstrative illustrations in the academic environment assists in the clarification and understanding of the subject of fixed prosthesis.

The new technologies have great importance in education; however, in order to be able to observe the real result it is required a team able to introduce the new feature, and, simultaneously, the material must present good quality ${ }^{8}$.

The clear manner with which the subject is dealt with in video-lesson demonstrating the step by step all the procedures draws attention of students, because it makes the lesson more 
dynamic awakening interest and leading them to seek their own knowledge independently ${ }^{5.9}$.

Pupulin et al..$^{5}$ in their study agree with the results of this research upon asserting that the process of production of videolesson and its use as a way of learning emphasizes that, when well prepared and with appropriate audiovisual language, its addition shows the image of the educator explaining and demonstrating content with rare characteristics of details and information, which favors the understanding of the student; however, the authors shall notify that such resource must be used.

There is a concern in relation to the exclusive use of video lesson lead to a minor engagement of students in pre-class activities. Students who are more "visual and auditive" must adapt better to the proposed video lessons, while kinesthetic students may prefer other types of activities, such as practical activities $^{10}$.

\subsection{Isolated}

A study done in the course of medicine, its results could observe that in the practice evaluation the performance of scholars subjected to the conventional method of teaching in the classroom associated to exposure to audio visual resource (video), in a general way, was higher than those exposed only to the usual method. The purpose of the introduction of any type of audiovisual resources is to allow students to associate what was explained in the classroom by supplementing and clarifying, in order to unite the alternative medium to the conventional one ${ }^{5}$.

Abranches et al. ${ }^{11}$ contemplated in their results that even being used as an supportive instrument for lectures, hypermedia can improve the student's performance, either by performing multiple media, or promoting greater interest. The episode of a lesson being complemented by resources of hypermedia has already demanded the need for greater preparation and greater time of the professor in its preparation, reaching a better-quality presentation.

The new teaching strategies can cause a clear progress in the implementation of the content taught, and also cause greater stimulus and interest. As all $t$ learning process involves the relationship between learner and instructor, cooperating and interacting consciously seeking a common goal, the significant role of the scholar is highlighted, whose performance requires continuous update of the foundations needed to implement the teaching ${ }^{12}$.

Regardless of the type of active methodology of teachinglearning process, one must understand that the force of inertia represents a great challenge to be faced when seeking changes in educational practice. In spite of several discussions on the matter, the controversy still present, is the centralization of learning in the educator and the transfer and deposit of knowledge, disregarding what the student has to add and discuss. Therefore, one should consider the proposal of education that the society wishes for its future generations ${ }^{13}$.
The active teaching methodologies, mainly through the video-lesson showed good results, however, there are still few scientific studies found in the literature, suggesting that, in this way, more research related to this important tool in the teaching-learning process.

\section{Conclusion}

The use of videoconference as an active teaching methodology in the academic environment has shown satisfactory results when applied in the classroom as an aid material, since most of the students have had success in most of the questions with the use this tool.

The technologies provide the professors the ability to innovate the class model, either by replacing the conventional lessons, or just using them as supportive material. The active methodologies can be a satisfactory alternative in the teaching-learning process to assist the teacher in the classroom, and its use can yield good results in the training of health professionals.

\section{References}

1. Christofoletti G, Fernandes J, Martins A, Oliveira Junior SA, Carregaro RL, Toledo A. Grau de satisfação discente frente à utilização de métodos ativos de aprendizagem em uma disciplina de Ética em saúde. Rev Eletr Educ 2014;8(2):18897.doi:14244/19827199823

2. Cotta RMM, Cazal MM, Rodrigues JFV, Gomes KO, Junqueria TS. Controle social no Sistema Único de Saúde: subsídios para construção de competências dos conselheiros de saúde. Physis 2010;20(3):853-72. doi: http://dx.doi.org/10.1590/ S0103-73312010000300009

3. Edginton A, Holbrook J. A blended learning approach to teaching basic pharmacokinetics and the significance of faceto-face interaction. Am J Pharm Educ 2010;74(5):88.

4. Nikzad S, SD SM, Azari ASD, SM. Effectof a Procedural Video CD andStudyGuideonthePracticalFixedProsthodontic performance ofiranian dental students. J Dental Educ 2012;76(3):354-9.

5. Pupulim GL, Ioris RA, Gama R, Ribas C, Malafalia O, Gama M. Aplicação de Recursos Audiovisuais no ensino da técnica operatória. Arq Bras Cir Dig 2015;28(4):234-8. doi: /10.1590/ S0102-6720201500040004.

6. Bergmann J, Sams A. Flip your classroom: reach every student in every class every day. USA: International Society for Technology in Education; 2012.

7. Bishop J, Verleger MA. The flipped classroom: a survey of the research paper. Washington: ASEE; 2013.

8. Rezende LA, Struchiner M. Uma Proposta pedagógica para produção e utilização de materiais audiovisuais no ensino de ciências: análise de um vídeo sobre entomologia. Rev Educ Ciênc Tec 2009;2(1):45-66.

9. Holanda V, Pinheiro Ak, Fernandes AF, Holanda E, Souza MA, Santos S M. Análise da produção científica nacional sobre a utilização de tecnologias digitais na formação de enfermeiros. Rev Eletr Enf 2013;15(4):1068-77. doi: 10.5216/ree.v15i4.20568

10. Williams DE. The future of medical education: flipping the classroom and education technology. Ochsner $\mathrm{J}$ 
2016;16(1):14-5.

11. Abranches D, Bardauil MR, Davidowicz H, Moura A, Ramos M. Composição e avaliação de aplicativo hipermídia como recurso educacional na graduação de Endodontia. Rev Inst Ciênc Saúde 2007;25(2):165-72.

12. Puig W, Ramos E R.Consideracionesgenerales de losmetodos de enseñanza y suaplicacionen cada etapa Del aprendizaje. Rev Haban Cienc Méd La Habana 2009;8(2):1-12.

13. Lima VV. Espiral construtivista: uma metodologia ativa de ensino-aprendizagem. Interface Comunic Saúd Educ 2017;21(61):421-34. doi: http://dx.doi.org/10.1590/180757622016.0316 